 \\ z Filologii Polskiej i Słowiańskiej
}

\author{
Цветанка Аврамова \\ (Софийски университет „Св. Климент Охридски“)
}

\section{Изразяване на посесивност (притежателност) в производната субстантивна лексика в българския и чешкия език}

\begin{abstract}
0.1. Според изследователите едва ли в някоя друга езикова категория се проявява така ярко „егоцентричността“ или „антропоцентричността“ на естествения език, както в категорията посесивност (Иванов, 1989, с. 6). Посесивността (притежателността) ${ }^{1}$ се смята за универсална понятийна категория, изразяваща се в отношение между две същности - собственик (possessor = посесор) и притежавано $($ possessum $=$ посесум $)($ вж. Иванов, 1989; Младенова, 2017, с. 10 и цит. там литература). Към отношението на притежание/принадлежност отнасям и отношението произход ${ }^{2}$. Споделям схващането, че както посесорът, така и посесумът могат да бъдат одушевена или неодушевена субстанция.
\end{abstract}

1 В настоящото изследване термините посесивност и притежателност се използват като синоними.

2 За изразяването на притежание/произход при някои деминутивни суфикси в германските и славянските езици в диахронен план вж. Петров, 2017.

This is an Open Access article distributed under the terms of the Creative Commons Attribution 3.0 PL License (creativecommons.org/licenses/by/3.0/pl/), which permits redistribution, commercial and non-commercial, provided that the article is properly cited. (c) The Author(s) 2018.

Publisher: Institute of Slavic Studies, Polish Academy of Sciences

[Wydawca: Instytut Slawistyki Polskiej Akademii Nauk] 
В славянските (и балканските) езици посесивността се изразява на различни езикови равнища, които са проучени в нееднаква степен. Във фокуса на изследователския интерес най-често са граматичните средства за изразяване на посесивност, докато семантичните аспекти попадат в центъра на вниманието едва през последните десетилетия (Младенова, 2017). ${ }^{3}$ На словообразувателно равнище в славянските езици посесивността обикновено се свързва със „суфиксите на притежателните прилагателни, префиксите на прилагателните със значение за отрицателна принадлежност, афиксите и др. средства за образуване на сложни думи с посесивно значение: мамин брат, безусый юнеи, коротконогий человек“" (вж. по-подробно Иванов, 1989, с. 112 и сл.; срв. също Костадинова, 2008, сс. 36-46), както и с някои глаголни префикси (Младенова, 2017). В субстантивната лексика посесивността почти не е изследвана. В монографията Категория посессивности в славянских и балканских языках (Иванов, 1989) за посесивност при съществителните имена се споменава единствено при сложните съществителни собствени от типа бълг. Петровден, Ботевград, срх. Кнешпоље (= Кнежје (кнезово) поље), рус. Ленинград, както и при нарицателни апозитивни конструкции („сложни съществителни, образувани от основи на две съществителни без интерфикс и суфикс“) от типа помощънкк-кмет, помощңник-министьр, помощник-аптекарка, заместник-министьр и др. (Иванов, 1989, сс. 209-210). В изследването на М. Костадинова Опозицията свой/чужд в чешкия и българския език е разгледан още един тип съществителни за изразяване на притежателност, назоваващи омъжените жени според професията или поста на техните съпрузи (Костадинова, 2008, с. 46; вж. т. 1.2.1.).

На речево равнище в българския език посесивност се изразява и с помощта на категорията определеност - чрез прибавяне на грамемата определителен член, срв. Жената (= 'моята жена / жена ми') е болна. Тази грамема обаче не е задължителна, т.е., както посочва Цв. Георгиева, посесорът може да има нулево означение, като той може да съвпада или да не съвпада с говорещото лице, срв. напр. Майка [= 'моята/нашата

3 Съществен принос в запълването на тази празнота е изследването на М. Младенова Семантика на посесивните глаголи в българския, чешкия и руския език (Младенова, 2017), която съпоставя глаголите за притежание в българския, чешкия и руския език в четири синхронни среза [началния период на книжовна дейност (X-XIв.), XIV в., XVII в. и съвременното състояние - XX-XXI в.], с оглед на функционирането им в речта. 
майка // майка ми/ни'] говори по телефона.; Не казвай на дядо [= 'моя/ нашия дядо//дядо ми/ни']!; Ще извикаме баба [= 'моята/нашата баба // баба ми/ни'] (посесорът съвпада с говорещото лице) и Не казвай на дядо! 'своя дядо // дядо си' (посесорът не съвпада с говорещото лице) (вж. по-подробно Георгиева, 2016, сc. 117-118).

В чешкия език посесорът има нулево означение, срв. Maminka [= 'moje maminka'] přšla (посесорът съвпада с говорещото лице). Neř́kej to mamince! [= 'své mamince'] (посесорът не съвпада с говорещото лице).

В изследването си Родството и роднинските названия в българския език (семантика и лексикографско представяне) Цв. Георгиева посочва различни типове роднински названия, изразяващи посесивност, вкл. т. нар. несъщински роднински названия, сред които субстантивирани притежателни и възвратно-притежателни местоимения (моят, твоят, mвоите, нашите, вашите, свочте и др.) (вж. по-подробно Георгиева, 2016).

Беглите ми наблюдения върху субстантивното словообразуване на славянските езици показват, че посесивността се изразява при много повече от споменатите в достъпната ми научна литература производни съществителни. Настоящото изследване е опит да бъдат систематизирани някои прояви на посесивност при съществителните, получени чрез деривация ${ }^{4}$ и универбиране ${ }^{5}$ в българския и чешкия език; на композитумите следва да бъде обърнато внимание в отделно изследване. Краткостта на изложението не позволява детайлното разглеждане на проблематиката, а само нейното най-общо маркиране.

0.2. Изследователите обръщат внимание на съществуващата нееднородност в структурата на посесивността като езикова категория. Изтъква се, че наред с категориални, притежателност се изразява и с некатегориални езикови средства, които, от своя страна, също могат да бъдат диференцирани в зависимост от семантиката на посесора (наличието или отсъствието в него на признаците 'одушевеност' 'неодушевеност', 'персоналност' 'неперсоналност', 'конкретност' 'абстрактност'), и от семантиката на посесума, който може да се характеризира с по-голяма

${ }^{4}$ Има се предвид словообразувателният начин деривация (= деривация в тесен смисъл); в широк смисъл деривация е синоним на словопроизводство (образуване на думи) изобщо.

5 За универбирането вж. Аврамова, 2018. 
или по-малка степен на отчуждаемост от съответния посесор (Иванов, 1989, с. 44). Принадлежността/собствеността традиционно се разделя на отчуждаема и неотчуждаема (вж. Иванов, 1989; Младенова, 2017, с. 13 и цит. там литература), но между двата типа понякога е трудно да се прокара рязка граница (Младенова, 2017, с. 13).

Една от характеристиките на посесивността е нейната рекурсивност (обратимост) - в зависимост от гледната точка (на посесора или на посесума) посесивността може да се разглежда като отношение на притежание (X има/притежава Y) и на принадлежност (Y принадлежи на X) (вж. Иванов, 1989, с. 4), като всяка от тези страни разполага със собствен набор от средства за изразяване (Иванов, 1989, с. 44).

Тези и други особености на посесивността, изследвана при притежателните местоимения, притежателните прилагателни и глаголите с посесивна семантика (вж. Иванов, 1989, с. 44), могат да се наблюдават и на равнище производна субстантивна лексика.

1.0. Като изхождам от принципното разбиране, че словообразувателните категории са деривационно въплъщение на определени ономасиологични (понятийни) категории (Dokulil, 1962, с. 75), смятам, че в субстантивното словообразуване универсалната понятийна категория посесивност се проявява на първо място чрез словообразувателната категория nomina posessiva ${ }^{6}$. В зависимост от гледната точка - на притежателя или на притежаемото, в нейните рамки се открояват две субкатегории, наречени nomina disponentis и nomina pertinentia ${ }^{7}$, чието значение може да се представи с парафразите 'X притежава Y' (nomina disponentis) и 'Y принадлежи на $\mathrm{X}^{8}$ (nomina pertinentia), където $\mathrm{X}=$ посесор, $\mathrm{Y}=$ посесум 9 .

6 Идеята за nomina posessiva е почерпана от Балтова, 1988.

7 За тези субкатегории вж. Аврамова, 2003.

8 В зависимост от това какво съдържание се влага в X и Y, парафразата може да е и с обърнат знак, в случая: 'Х принадлежи на $Y^{\prime}$, като под X се разбира посесум, а под $\mathrm{Y}$ - посесор.

9 В предишни свои разработки (Аврамова, 2003 и др.) съм разгледала потіna disponentis и nomina pertinentia като отделни словообразувателни категории. Предвид на това, че и двете изразяват посесивност (отношение на притежание или принадлежност), а различна е само гледната точка - на притежателя или на притежаемото, по-адекватно е те да бъдат смятани за две подкатегории (субкатегории) на единната категория nomina posessiva. 
1.1. За разлика от потina pertinentia, субкатегорията nomina disponentis е монолитна - посесорът $\mathrm{X}$, изразен чрез словообразувателния формант (СФ), винаги се характеризира с признака '+ одушевеност', '十 персоналност', а посесумът Ү, изразен чрез словообразувателната основа (СО), с признаците '- одушевеност', ‘ конкретност'. Към тази субкатегория се отнасят названията на лица, притежаващи определен обект, напр.: трабантаджия 'този, който притежава трабант', голфаджия 'този, който притежава лек автомобил марка Голф', ресторантьор който притежава фирма', никонаджия 'този, който притежава фотоапарат марка Никон'; чеш. butikár. 'ten, kdo má butik', džípařr 'ten, kdo má džíp', saunér

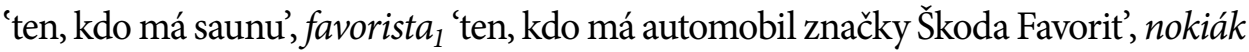
и nokiář 'ten, kdo má mobilní telefon značky Nokia'.

1.2. В зависимост от допълнителните семантични признаци, характеризиращи X и Y (‘ \pm одушевеност’, ‘ \pm персоналност '10 , \pm пол’, ‘ \pm конкретност'), nomina pertinentia се разделя на няколко семантични типа. На формално равнище при потina pertinentia посесорът Х се изразява чрез СО, а посесумът Ү - чрез СФ.

1.2.1. Y ('+ одушевеност', ‘+ персоналност', ‘+ женски пол’) принадлежи на X ('+ одушевеност' ‘ + персоналност', '+ мъжки пол') ${ }^{11}$. Този семантичен тип обхваща названията на лица от женски пол, които са в съпружески отношения с лица от мъжки пол. Както е известно, съпружеските отношения са отношения на принадлежност: двамата съпрузи взаимно си принадлежат, напр. депутатша, дипломатиа, докторша, митничарша, офицерша, президентша, премиерша; чеш. (рапí) doktorová, profesorová, ředitelová, plukovníková, prezidentová и др. Същото значение изразяват и някои съществителни собствени, които обаче не са обект на изследването ${ }^{12}$.

10 Признакът 'персоналност' съдържа признака 'одушевеност' и го конкретизира, но за по-голяма яснота тук двата признака се посочват отделно.

11 В парафразите на значението са включени само признаците, релевантни за неговото определяне, т.е. в някои парафрази дадени признаци (напр. 'пол') отсъстват (вж. т. 1.2.3. - 1.2.6.). Признакът 'пол' е посочен само с конкретизациите 'мъжки пол', 'женски пол' (вж. т. 1.2.1., 1.2.2.).

12 За сравнение ще посоча само няколко примера: Иваница 'жена = съпруга на Иван' (остар.), Петровииа 'жена = съпруга на Петър' (остар.) и др.; чеш. (paní) Olivová, Čechová, Pospíšilová и др. Освен отношение на принадлежност между две лица, които са съпрузи, съществителните собствени изразяват и отношение на принадлежност 
1.2.2. Y ('十 одушевеност', ‘+ персоналност', ‘+ мъжки пол') принадлежи на X ('+ одушевеност' '+ персоналност', '+ женски пол'). Назоваването на съпруга чрез името на съпругата се среща само в българския език. При нарицателните имена този тип номинация е характерен за някои роднински названия, напр. лелѝн 'съпруг на леля', тетѝн диал. 'съпруг на тетка', зблвеник 'съпруг на зълва'

Освен съпружеска принадлежност, в българския език може да се назовава и друг тип роднинска принадлежност, напр. сестриник 'син на сестрата по отношение на нейните братя и сестри'. Това съществително е получено чрез универбиране от словосъчетанието сестрин син, т.е. то наследява посесивната семантика от произвеждащата основа сестрин.

1.2.3. Y ('+ одушевеност', ‘+ персоналност’) принадлежи на X ('+ одушевеност' '十 персоналност'). Тук се включват названията на лица, привърженици, последователи на идеите, възгледите на друго лице - създател на научно, идейно, политическо, творческо и др. направление, течение, организация, напр. хегелианеи, дъновист, йеховист, костовист; чеш. darwinista, jehovista, havlovec, klausovec/klausista и др.

1.2.4. Y ('+ одушевеност', '+ персоналност') принадлежи на $\mathrm{X}$ ('+ конкретност', ‘- одушевеност’). Този семантичен тип обхваща названия за принадлежност към даден колектив, организация и под., напр. бълг. левскар, иесекар, бесепар, партиеи; чеш. spartan, ódéesák/odéesák, grínpísák, straník.

1.2.5. Y ('+ одушевеност', п персоналност') принадлежи на (произхожда от) X ('- одушевеност', '十 конкретност'). Това са т. нар. nomina habitatorum - названия за принадлежност към определено място (в широк смисъл), напр. софиянеи, мексиканеи, европееи, лондончанин, бургазлия, селянин; чеш. Pražan, Asiat, Portugálec, Američan, Moravan, ostrovan.

1.2.6. Y ('- одушевеност', '十 конкретност') принадлежи на (произхожда от) X ('- одушевеност,' ‘ конкретност'). Тук се включват терминологичните названия на минерали, вещества и др. според мястото на откриването или

между роднини изобщо, напр. между дъщеря и баща, срв. Иванова, 'дъщеря на Иван' [суфикс -ов(а)] и Иванова 2 'сьпруга на Иванов' (формант -a), чеш. Krejčová 'manželka pana Krejčího’ [(суфикс -ov(á)] и Krejčová ‘ ‘dcera pana Krejčího’ [(суфикс -ov(á)].

13 Срв. при собствените имена: Генко Гинкин (мъжът на Кака Гинка от Под игото на Иван Вазов); Нонин (презиме на мъж, образувано от личното име на майката), Петканчин (от Петканииа) и др. (Граматика на съвременния български книжовен език, 1983, с. 74). 
находището им, напр. амазонит $(\leftarrow$ Амазонка), мурманит $(\leftarrow$ Мурманск), тюрингит ( $\leftarrow$ Тюрингия); чеш. aragonit $(\leftarrow$ Aragonie), dolomit $(\leftarrow$ Dolomity) и др.

1.3. Представеното описание на категорията nomina posessiva няма претенции за изчерпателност. Надявам се то да послужи като отправна точка за бъдещи изследвания, които да обемат и останалата част от производната субстантивна лексика в двата езика.

2.0. Посесивност изразяват и съществителни извън категорията nomina posessiva. В тяхната семантика отношението на притежание/ принадлежност сякаш е скрито, не изпъква на преден план, т.е. при тях посесивната сема е в комбинация с друга сема / други семи, която/които се приема/т за водещ/и.

2.1. Така например посесивност в българския език изразяват и съществителни nomina quantificativa от типа дядови, вуйчови, чичови, бабини, лелини, стринкин ${ }^{14}$, назоваващи сборно множество, включващо всички лица от семейството на лицето, означено с мотивиращото име. Тези съществителни са образувани от роднински названия с помощта на суфикс-ови (от произвеждащи основи в мъжки или среден род) и -ини (от произвеждащи основи в женски род) (вж. по-подробно Аврамова, 2010).

В полски подобен тип множество назовават съществителни от типа profesorstwo 'profesor i jego żona': множество, състоящо се от двама души, които се намират в съпружески отношения, т.е. отношения на принадлежност; срв. също doktorostwo, dyrektorostwo, synostwo, wujostwo и др. (Иванов, 1989, с. 46; Българско-полска съпоставителна граматика, 1994, с. 86).

2.2. Скрита посесивност има и при съществителни от категорията nomina attributiva, назоваващи субстанция (в случая: лице), характеризирана според наличието на специфичен признак, белег, черта, напр. двойкар 'този (= ученик/студент), който често получава двойки (на изпит)', гърбушко 'този, който има гърбица', шкембелия разг. 'този, който има (голямо) шкембе', глупак ['този, който е глупав (= има, притежава качеството 'глупав')]; чеш. břicháč 'ten, kdo má velké břicho', hlavoun 'ten, kdo má velkou hlavu', hlupák 'ten, kdo je hloupý' [= má vlastnost 'hloupý'].

\footnotetext{
${ }^{14}$ Също при съществителните собствени: Иванови, Стоянови, Буденброкови, Гулденбургови; чеш. Přemyslovci, Habsburkové (Petr, 1986, с. 49).
} 
2.3. Девербалните съществителни, производни от глаголи, съдържащи посесивни предикати, унаследяват посесивната сема (при някои от тях съчетана с каузативна сема) на произвеждащите ги глаголи, напр. притежател; дарител, получател, носител, владетел, спестовник, дльжник, разсипник, обирник/обирджия разг., раздавач, продавач, препродавач, купувач, прекупвач, откупвач, преносвач, наследник и др.; чеш. dárce, majitel, držitel, vlastník, prodavač, nákupce, spořitel, dlužník, vládce и др.

3.0. Представеното изложение няма претенции да опише в пълнота всички прояви на посесивност при субстантивните деривати в двата езика. Неговата основна цел е да покаже, че посесивност в българския и чешкия език изразяват не само притежателните прилагателни (за лична и обща принадлежност), притежателните и възвратно-притежателните местоимения, някои глаголи и субстантивни композитуми, посочвани най-често като примери в научните трудове, но и други производни съществителни, на които в изследванията е обръщано по-малко внимание или изобщо не е обръщано внимание от гледна точка на притежателността.

3.1. Направената съпоставка показва, че българският език се отличава с по-голямо разнообразие при назоваването на посесивните отношения. Типът номинация, при който съпругът се назовава чрез съпругата (т. 1.2.2.), не е представен в чешкия език; само в българския се срещат и съществителни pluralia tantum от типа дядови, бабини със събирателно значение, включващо и посесивна сема (т. 2.1.).

Назоваването на лицето от женски пол чрез лицето от мъжки пол, с което това лице е в съпружески (или други роднински) отношения, е езиково отражение на света, в който централно (и господстващо) място се отрежда на Мъжа. В българския и чешкия превод на Библията с една и съща дума се назовава мъж и човек, а за жена има отделна дума, срв. „И създаде Господ Бог от реброто, взето от човека, жена, и я заведе при човека“ (Първа книга Мойсеева - Битие 2: 22) ${ }^{15}$. „A Hospodin Bůh utvořil z žebra, které vzal $\mathrm{z}$ člověka, ženu a přivedl ji k němu“" (První Mojžíšova - Genesis 2: 22) ${ }^{16}$.

${ }^{15}$ Библия или книгите на Свещеното писание на Стария и Новия завет. Света Гора, Атон, Славянобългарски манастир „Св. вмчк Георги Зограф“, 2009.

${ }^{16}$ Bible. Písmo svaté starého a nového zákona. Český ekumenický překlad. Česká biblická společnost, 1992. 


\section{Съкращения}

СО - словообразувателна основа

СФ - словообразувателен формант

\section{Литература}

Dokulil, M. (1962). Tvoření slov v češtině: 1. Teorie odvozování slov. Praha: Academia.

Petr, J. (Ed.). (1986). Mluvnice češtiny: 2. Tvarosloví. Praha: Academia.

Аврамова, Ц. (2003). Словообразувателни тенденции при съществителните имена в българския и чешкия език в края на ХХ век. София: Херон Прес.

Аврамова, Ц. (2010). За граматичния и лексикален статус на някои названия за сборно множество в съвременния български книжовен език. In Ц. Аврамова, Ц. Георгиева, Х. Холиолчев, \& Л. Крумова-Цветкова (Eds.), Слово и словесност: Сборник в чест на 70-годишнината на ст.н.с. д-р Юлия Балтова (рр. 195-204). София: Емас.

Аврамова, Ц. (2018). Универб(из)ация и езикова икономия в славянските езици. In A. Šehović (Ed.), Univerbacija/univerbizacija u slavenskim jezicima (pp. 43-58). Sarajevo: Slavistički komitet Sarajevo. Retrieved June 19, 2018, from http://www.slavistickikomitet .ba/Univerbacija/Univerbizacijauslavenskimjezicima.pdf

Балтова, Ю. (1988). Структура и семантика на суфиксалните съществителни имена в съвременния български книжовен език. Unpublished manuscript.

Българско-полска съпоставителна граматика: 3. Семантичните категории количество и степен. (1994). София: Академично издателство „Марин Дринов“.

Георгиева, Ц. (2016). Родството и роднинските названия в българския език (семантика и лексикографско представяне). София: Авангард Прима.

Граматика на съвременния български книжовен език: Том 2. Морфология. (1983). София: Издателство на БАН.

Иванов, В. В. (Еd.). (1989). Категория посессивности в славянских и балканских языках. Москва: Наука.

Костадинова, М. (2008). Опозицията свой/чужд в чешкия и българския език. София: Стигмати.

Младенова, М. (2017). Семантика на посесивните глаголи в българския, чешкия и руския език (Автореферат на дисертационен труд за присъждане на научната степен „доктор на филологическите науки“). София.

Петров, И. П. (2017). Някои славяно-германски паралели в структурата и произхода на деминутивните суфикси. In М. Стефанов, П. Мартинова, Д. Григоров, Р. Петрова, В. Колев, \& Т. Георгиева (Eds.), Мултикултурализъм и многоезичие: Сборник с доклади 
от Тринадесетите международни славистични четения София, 21-23 април 2016 г.: T. 1. Лингвистика (рр. 428-435). Велико Търново: Фабер.

Топоров, В. Н. (1986). О некоторых предпосылках формирования категории посессивности. In Славянское и балканское языкознание: Проблемы диалектологии: Категория посессивности (рр. 142-166). Москва: Наука.

\section{Bibliography (Transliteration)}

Avramova, T. (2003). Slovoobrazuvatelni tendentsii pri sŭshtestvitelnite imena $v$ bŭlgarskiia $i$ cheshkiia ezik v kraia na XX vek. Sofiia: Kheron Pres.

Avramova, T. (2010). Za gramatichniia i leksikalen status na niakoi nazvaniia za sborno mnozhestvo v sŭvremenniia bŭlgarski knizhoven ezik. In T. Avramova, T. Georgieva, K. Kholiolchev, \& L. Krumova-TSvetkova (Eds.), Slovo i slovesnost: Sbornik v chest na 70-godishninata na st.n.s. d-r IUliia Baltova (pp. 195-204). Sofiia: Emas.

Avramova, T. (2018). Univerb(iz)atsiia i ezikova ikonomiia v slavianskite ezitsi. In A. Šehović (Ed.), Univerbacija/univerbizacija u slavenskim jezicima (pp. 43-58). Sarajevo: Slavistički komitet Sarajevo. Retrieved June 19, 2018, from http://www.slavistickikomitet.ba/ Univerbacija/Univerbizacijauslavenskimjezicima.pdf

Baltova, I. (1988). Struktura i semantika na sufiksalnite sŭshtestvitelni imena v sŭvremenniia bŭlgarski knizhoven ezik. Unpublished manuscript.

Bŭlgarsko-polska sŭpostavitelna gramatika: 3. Semantichnite kategorii kolichestvo i stepen. (1994). Sofiia: Akademichno izdatelstvo "Marin Drinov".

Dokulil, M. (1962). Tvoření slov v češtině: 1. Teorie odvozování slov. Praha: Academia.

Georgieva, T. (2016). Rodstvoto i rodninskite nazvaniia v bŭlgarskiia ezik (semantika i leksikografsko predstaviane). Sofiia: Avangard Prima.

Gramatika na sŭvremenniia bŭlgarski knizhoven ezik: Tom 2. Morfologiia. (1983). Sofiia: Izdatelstvo na BAN.

Ivanov, V. V. (Ed.). (1989). Kategoriia posessivnosti v slavianskikh i balkanskikh iazykakh. Moskva: Nauka.

Kostadinova, M. (2008). Opozitsiiata svoŭ/chuzhd v cheshkiia i bŭlgarskiia ezik. Sofiia: Stigmati.

Mladenova, M. (2017). Semantika na posesivnite glagoli v bŭlgarskiia, cheshkiia i ruskiia ezik (Avtoreferat na disertatsionen trud za prisŭzhdane na nauchnata stepen "doktor na filologicheskite nauki”). Sofiia.

Petr, J. (Ed.). (1986). Mluvnice češtiny: 2. Tvarosloví. Praha: Academia.

Petrov, I. P. (2017). Niakoi slaviano-germanski paraleli v strukturata i proizkhoda na deminutivnite sufiksi. In M. Stefanov, P. Martinova, D. Grigorov, R. Petrova, V. Kolev, \& T. Georgieva (Eds.), Multikulturalizŭm i mnogoezichie: Sborniks dokladi ot Trinadesetite mezhdunarodni slavistichni cheteniia Sofiia, 21-23 april 2016 g.: T. 1. Lingvistika (pp. 428-435). Veliko Tŭrnovo: Faber. 
Toporov, V. N. (1986). O nekotorykh predposylkakh formirovaniia kategorii posessivnosti. In Slavianskoe i balkanskoe iazykoznanie: Problemy dialektologii: Kategoriia posessivnosti (pp. 142-166). Moskva: Nauka.

\section{Expression of possessiveness in derivative substantive vocabulary of the Bulgarian and Czech languages}

\section{Summary}

The article is dedicated to researching the manifestations of possessiveness in some nouns of the Bulgarian and Czech languages. We start from the definition of possessiveness as a relation between the objects of extralinguistic reality, whereby one is the possessed object (possessum), the other one is its holder (possessor). In possessive semantics, a central place amidst the nouns is assigned to the nomina posessiva. Nevertheless, possessiveness is also expressed by nouns belonging to other word formation categories, where possessive semantics is not the leading one.

\section{Sposoby wyrażania posesywności w derywatach rzeczownikowych języka bułgarskiego i czeskiego}

\section{Streszczenie}

Artykuł rozpatruje sposoby wyrażania posesywności niektórych rzeczowników w języku bułgarskim i czeskim. Podstawą jest definicja posesywności jako stosunku między obiektami z rzeczywistości pozajęzykowej, z którym jeden jest obiektem posiadania (possessum), a drugi posiadaczem (possessor). Centralne miejsce wśród rzeczowników z semantyką posesywną 
zajmują nomina posessiva. Posesywność wyrażana jest jednak również przez rzeczowniki z innych kategorii słowotwórczych, w których nie dominuje semantyka posesywna.

Keywords: possessiveness; possessor; possessum; word formation; noun

Słowa kluczowe: posesywność; possessor; possessum; słowotwórstwo; rzeczownik

Tsvetanka Avramova, Faculty of Slavic Studies, St. Kliment Ohridski University, Sofia Correspondence: avramova.cv@slav.uni-sofia.bg

This work has been self-funded by the author.

Competing interests: The author has declared she has no competing interests. 